\title{
HUBUNGAN KERJA ANTARA JURAGAN DAN ANAK BAGAN DALAM KEHIDUPAN NELAYAN
}

\section{WORK RELATIONSHIP BETWEEN JURAGAN AND ANAK BAGAN OF FISHERMEN LIVES}

\author{
S H Putri1a \\ 1Magister Ilmu Sejarah Fakultas Ilmu Budaya Universitas Andalas \\ Jl. Universitas Andalas, Limau Manis, Kec Pauh, Kota Padang, Sumatra Barat. \\ a Korespondensi: Sri Haryati Putri E-mail: Sriharyatiputri@gmail.com \\ (Diterima: 23-09-2019; Ditelaah: 25-09-2019; Disetujui: 27-02-2020)
}

\begin{abstract}
In stark view, the fishing profession is considered a qualification of the poor, because it is plagued by limitations of quality human resources, access, mastery of technology, markets, and capital. Apparently, not all fishermen are categorized as retarded. Skipper as a financier acts as a landlady to live well off compared to other communities. This writing uses the method of writing history which aims to reveal the other side of the lives of fishermen, particularly labor fishermen who only have the capital and simple fishing equipment, only depend their livelihood on a juragan as the owner of anak bagan. Thus, a patron-client relationship exists between juragan and anak bagan. The other side revealed that the relationship between juragan and anak bagan contained elements of exploitation and dominance. Nevertheless, patron-client relationship patterns are more subtle and invisible. The anak bagan does not feel that there is exploitation because the provision of assistance in the form of debt from juragan is much greater and takes place intensively and in a long time.

Keywords: Anak bagan, fishermen, juragan, patron-client.
\end{abstract}

\begin{abstract}
ABSTRAK
Secara kasat mata, profesi nelayan dianggap sebagai kualifikasi masyarakat miskin, karena didera keterbatasan di bidang kualitas sumber daya manusia, akses, penguasaan teknologi, pasar dan modal. Ternyata, tidak semua nelayan dikategorikan dengan kehidupan terbelakang. Juragan sebagai modal bertindak sebagai induk semang hidup berkecukupan dibandingkan dengan masyarakat lainnya. Penulisan ini menggunakan metode penulisan sejarah yang bertujuan untuk mengungkapkan sisi lain dari kehidupan nelayan, terutama nelayan buruh yang hanya bermodalkan tenaga beserta alat pancing sederhana, hanya menggantungkan penghidupannya pada seorang juragan selaku pemilik bagan. Maka, terjadilah relasi patron-klien antara juragan dan anak bagan. Sisi lain mengungkapkan bahwa hubungan antara juragan dan anak bagan mengandung unsur eksploitasi dan dominasi. Tetapi, pola hubungan patron-klien lebih halus dan tak terlihat. Klien (anak bagan) tidak merasa adanya eksploitasi tersebut, karena pemberian bantuan berupa utang dari juragan jauh lebih besar dan berlangsung intensif serta dalam jangka panjang.

Kata kunci: Anak bagan, juragan, nelayan, patron-klien.

Putri, S. H. (2020). Hubungan Kerja Antara Juragan dan Anak Bagan Dalam Kehidupan Nelayan. Jurnal Sosial Humaniora, 11(1), 15-28.
\end{abstract}




\section{PENDAHULUAN}

Masyarakat nelayan merupakan salah satu bagian masyarakat yang hidup dengan mengelola potensi sumberdaya perikanan. Namun, kesulitan untuk melepaskan diri dari belenggu kemiskinan karena mereka didera oleh beberapa keterbatasan di bidang kualitas sumber daya manusia, akses, penguasaan teknologi, pasar dan modal (Kusnadi,2009). Seperti yang juga dialami oleh masyarakat lainnya, masyarakat nelayan menghadapi sejumlah masalah, termasuk politik, sosial, dan ekonomi yang kompleks. Sehingga, nelayannelayan di wilayah pesisir adalah lemah kedudukannya dalam permodalan, lemah dalam akses memperoleh kredit bank, lemah dalam pendidikannya, lemah dalam sarana atau peralatan produksinya, serta lemah dalam menghadapi faktor-faktor alam, perubahan musim dan pasar, sehingga kehidupan nelayan tetap miskin (Rahardjo Adisasmita,2015).

Akan tetapi, secara garis besar kenyataan lapangan mengungkapkan bahwa kehidupan seperti ini tidak dialami oleh juragan pemilik kapal bagan. Bekal beserta alat tangkap melaut yang tidak murah, yakni mencapai 500 hingga 800 juta rupiah harga satu unit bagan, hanya dapat dipenuhi oleh seorang juragan. Berbeda jauh dengan apa yang dimiliki oleh anak bagan, mereka hanya bermodalkan alat tangkap berupa pancing sederhana yang berukuran kecil. Tentu mereka mendapatkan penghasilan yang tidak seberapa dibandingkan dengan juragan sebagai pemilik kapal.

Secara kasat mata, orang yang bekerja di laut disebut sebagai nelayan. Namun, dalam penerapan sistem kerja terdapat stratifikasi yang begitu jelas. Anak bagan hanya menggantungkan perekonomiannya pada pemilik bagan sebagai penyedia lapangan kerja. Kebutuhan perekonomian yang kian terus meningkat, tanpa ada pilihan anak bagan harus menjalani kehidupan dengan perekonomian yang serba terbatas.
Sehingga anak bagan hidup dalam taraf ekonomi ke bawah dan tergolong miskin yang berbeda jauh dengan pemilik bagan yang hidup berkecukupan dan tergolong kaya.

Oleh karena itu, kajian maritim seperti ini layak untuk dikaji dan diteliti lebih lanjut. Sesuai dengan ungkapan sejarawan maritim kenamaan yakni AB Lapian, kajian sejarah maritim bukan lagi merupakan hal yang pantas dilakukan, merupakan suatu yang wajib mendapat prioritas. Menurutnya, melihat sejarah Indonesia dari darat saja membawa akibat pengetahuan dan pandangan tentang masa lampau dan masa kini selalu berat sebelah. (Abd. Rahman Hamid, 2015). Keduanya harus ditempatkan sesuai konteksnya, sehingga diperoleh sejarah nasional yang beraspirasi sejarah tanah air.

\section{MATERI DAN METODE}

\section{Materi}

\section{Peran Sosial Ekonomi Juragan dalam Kehidupan Masyarakat}

Profesi nelayan tidak harus menamatkan pendidikan dalam jenjang ilmu tertentu, cukup memiliki kemauan dan berani melaut dengan segala bentuk resiko yang akan terjadi. Tentu ini tidaklah mudah dan tidak semua orang dapat menjalaninya sebagai mata pencaharian untuk menyambung hidup. Profesi ini butuh seseorang yang bermental baja, karena apapun dapat terjadi apabila kapal telah memasuki muara laut lepas (Syahrizal,2011). Nelayan sering diceritakan sebagai orang yang hidupnya terancam bahaya. Hujan badai yang mengganas atau arus laut yang deras bisa membuat kapal mereka tenggelam.

Para nelayan merupakan pekerja-pekerja handal yang memiliki dedikasi tinggi terhadap pekerjaannya. Seorang juragan tanpa banyak pertimbangan akan menerima siapapun yang mau bekerja baik sebagai 
ABK maupun buruh gudang tempat letak ikan setelah proses pengawetan (Rokhmin Dahuri,2004). Baik nelayan penuh maupun nelayan sambilan, mereka bekerja di bawah usaha-usaha dagang yang dijalankan oleh para juragan pemilik bagan. Para pekerja ini biasanya berumur sekitar 18 tahun ke atas, dari yang muda hingga yang paling tua asalkan berjenis kelamin laki-laki dapat diterima oleh juragan untuk bekerja pada usaha perikanan yang dijalankannya.

Semua pembagian kerja diatur dan ditetapkan oleh juragan. Tidak ada pertikaian berarti yang dapat terjadi di antara sesama pekerja. Hal ini dilatarbelakangi oleh hubungan emosional dan sosial antar sesama nelayan terjalin begitu erat, terutama hubungan antara juragan dan anak bagan sebagai pekerjanya. Hubungan kekerabatan seperti itu dapat terlihat pada peminjaman modal dari juragan kepada nelayan buruh agar nelayan tersebut juga dapat menangkap ikan di laut (M.Firza,2011). Peminjaman modal tersebut bisa berupa uang maupun perahu dan alatalat penangkapan ikan yang menjadi kebutuhan seorang nelayan. Secara tidak langsung dengan adanya gotong royong dan tolong menolong seperti itu dapat mempengaruhi kehidupan ekonomi nelayan terutama nelayan buruh yang kekurangan modal. Salah satu alternatif tempat peminjaman uang hanyalah pada juragan (Herman Sinaga,2015). Masyarakat nelayan merupakan unsur sosial yang sangat penting dalam struktur masyarakat pesisir, maka kebudayaan dalam semangat berbagi yang mereka miliki, mewarnai karakteristik kebudayaan atau perilaku sosial ekonomi masyarakat pesisir secara umum.

\section{Anak Bagan dalam Sistem Ekonomi Masyarakat}

Nelayan miskin datang dari latar belakang keluarga yang sebenarnya beragam. Tidak semua mereka mempunyai orang tua yang juga awalnya bekerja sebagai nelayan. Mereka juga ada yang berasal dari keluarga atau orang tua yang bekerja sebagai petani, pedagang, bahkan ada juga di antara mereka yang datang merantau dari daerah pedalaman (Mochtar Naim,2013). Mereka yang berasal dari keluarga petani senantiasa mengatakan bahwa kehidupan orang tua mereka yang susah tidak memiliki tanah atau lahan yang cukup bagi anak-anaknya untuk bertani, maka jalan satu-satunya untuk menyambung penghidupan hanya bekerja di sektor kelautan sebagai nelayan. Kemudian, anak bagan ataupun buruh nelayan lainnya, tidak hanya berasal dari masyarakat pinggir pantai yang sedari kecil sudah akrab dengan laut, tetapi juga perantauan dengan negeri asal yang sama sekali tidak berdekatan dengan laut, kemudian juga memutuskan untuk menjadi seorang nelayan. Selain didorong oleh jiwa perantauan orang Minangkabau, mereka juga mendapatkan peruntungan dengan berjodoh dengan perempuan pesisir.

Perbedaan kondisi antara pemilik bagan dan anak bagan sudah menjadi lumrah. Masyarakat pesisir pantai sebenarnya mampu untuk hidup dengan taraf perekonomian yang cukup lumayan dan tergolong kaya, asalkan punya modal finansial yang mencukupi (Aswardi Bakar,2016). Sayangnya, ini hanya bisa penuhi oleh pemilik bagan dengan kondisi keuangan yang baik. Tidak ada pilihan lain, didukung dengan biaya hidup yang kian terus meningkat, kondisi seperti ini yang mengharuskan masyarakat nelayan untuk menjalani hidup seperti ini. Sehingga, dari dahulu memang tidak ada titik terang untuk menyelesaikan masalah tersebut, baik bagi pemerintah daerah maupun masyarakat sendiri.

\section{Metode}

Metode yang digunakan dalam penulisan ini adalah dengan menggunakan metode sejarah yang dibagi kedalam empat tahapan, yakni heuristik, kritik, interpretasi dan historiografi (Louis Gottschalk,2007). Mestika Zed mengatakan bahwa metode sejarah adalah proses menguji dan menganalisis secara kritis rekaman 
peninggalan masa lampau berdasarkan data yang diperoleh dengan menempuh proses yang berwujud historiografi. Dalam hal ini metode sejarah digunakan agar dapat merekonstruksi kembali peristiwa masa lampau, sehingga dapat diuji kebenarannya (Mestika Zed,1999).

Tahap pertama, yakni heuristik (pengumpulan sumber). Sumber-sumber yang didapatkan dari hasil studi perpustakaan dan hasil wawancara dengan pelaku sejarah yang dapat dijadikan sebagai informan. Studi pustaka dilakukan ke berbagai perguruan tinggi yang ada di Sumatera Barat, khususnya kota Padang. Seperti, penelusuran pustaka pusat Unand, pustaka PPs Unand, pustaka jurusan Magister (S2) Unand serta pustaka pusat UNP, kemudian tidak ketinggalan perpustakaan daerah Sumatera Barat. Arsip Provinsi Sumbar, arsip kota Padang, dan BPS kota Padang. Selanjutnya, sumber penting lainnya dapat ditemukan di kantor arsip daerah Pesisir Selatan, Dinas Kelautan dan Perikanan Pesisir Selatan, dan BPS Pesisir Selatan.

Selain menggunakan sumber tulisan, sumber lisan tidak kalah pentingnya dalam merekonstruksi fakta sejarah, hal ini bisa dilakukan dengan wawancara. Wawancara bisa dilakukan kepada pelaku sejarah yang masih hidup yang terlibat langsung dengan dunia kemaritiman dan bekerja sehari-hari berhubungan dengan laut. Di antaranya, Siin, Ijon, Asis, Zainal, Isap, Emen dan Cendri, serta seluruh elemen masyarakat yang mengetahui tentang dinamika kehidupan masyarakat nelayan di Nagari Air Haji.

Tahapan kedua adalah melakukan kritik sumber. Sumber yang telah didapat terlebih dahulu dilakukan kritik intern (untuk memastikan kebenaran isi) dan kritik ekstern (untuk mencari keaslian sumber). Kritik ekstern ini pada dasarnya bertujuan untuk melihat apakah sumber-sumber yang telah didapat tadi benar-benar asli. Sedangkan kritik intern bertujuan untuk memastikan kebenaran isi yang telah didapat dari sumber-sumber tadi.

Tahapan selanjutnya adalah interpretasi data, setelah melalui tahapan kritik sumber, kemudian dilakukan tahap interpretasi atau penafsiran terhadap fakta sejarah yang diperoleh dari arsip, buku-buku yang relevan dengan sejarah sejarah maritim serta perdagangan laut yang maupun hasil penelitian langsung di lapangan. Tahapan ini menuntut kehati-hatian dan integritas penulis untuk menghindari interpretasi yang subyektif terhadap fakta yang satu dengan fakta yang lainnya, agar ditemukan kesimpulan atau gambaran yang ilmiah.

Tahap terakhir adalah historiografi. Merupakan proses penulisan fakta-fakta yang diperoleh dari data-data yang ada (Helius Sjamsuddin,2012). Proses penulisan dilakukan agar fakta-fakta yang telah di interpretasikan satu sama lain dapat disatukan sehingga menjadi satu perpaduan yang sistematis dalam bentuk narasi kronologis.

\section{HASIL DAN PEMBAHASAN}

\section{Penduduk dan Mata Pencaharian}

Nagari Airhaji memiliki dua pusat atau sentral daerah terbanyak masyarakatnya yang berprofesi sebagai nelayan, yakni terdapat di Kampung Muaro Gadang dan Kampung Muaro Airhaji. Kedua kampung ini masyarakatnya hidup dan tinggal di daerah dekat pesisir pantai. Kampung Muaro Airhaji merupakan salah satu kampung yang masyarakatnya paling banyak berprofesi sebagai nelayan. Sebagaimana lazimnya kehidupan masyarakat nelayan, mereka memang tinggal dekat dengan laut di tepi pesisir pantai. Sehingga mata pencaharian utama masyarakatnya adalah dengan memanfaatkan hasil tangkapan yang biasa dikenal dengan nelayan. Sehingga apabila dipresentasikan, masyarakat yang berprofesi sebagai nelayan adalah sekitar $75 \%$. Sementara, 25\% lainnya berprofesi 
sebagai petani, saudagar, pegawai dan lain sebagainya (Cendri Delvino,2018).

Terlihat berbeda dengan Nagari Muaro Gadang, yang memiliki keunikan tersendiri bagi masyarakatnya. Profesi nelayan hanyalah sebagai mata pencaharian sambilan, sementara profesi utama mereka adalah sebagai petani, terutama petani sawit. Hal ini diakibatkan oleh Nagari Muaro Gadang dikenal sebagai pusat tanaman sawit terbesar di Kecamatan Linggo Sari Baganti. Dipresentasikan bahwa masyarakat yang berprofesi sebagai nelayan yang menggantungkan kehidupannya pada hasil laut hanyalah sekitar $10 \%$. Sementara $90 \%$ masyarakat lainnya berprofesi di darat dengan menggantungkan perekonomian pada hasil alam, yakni berupa sawit, kelapa, semangka, jagung, dan beragam jenis tanaman lainnya (Data Nagari,2016).

Tidak tertariknya masyarakat bekerja dengan memanfaatkan sektor kelautan, disebabkan oleh berbagai faktor. Terutama faktor permasalahan ekonomi kelautan yang semakin diperumit. Mulai dari razia alat tangkap, birokrasi pengurusan surat izin kapal yang dipersulit, mahalnya harga bahan bakar dan permasalahan lainnya yang dapat mengganggu kelangsungan hidup nelayan. Umumnya mereka hanya berstatus sebagai nelayan buruh karena tidak memiliki modal untuk membeli kapal beserta alat tangkap selama melaut. Sementara itu, mereka punya lahan dan tanah yang cukup apabila digunakan untuk bertani. Tidak jarang masyarakat Nagari Muaro Gadang Airhaji merangkap dua jenis pekerjaan sekaligus. Disamping mereka juga berprofesi sebagai nelayan, mereka juga bekerja di sektor pertanian dan berhasil membangkitkan perekonomian dengan menjadi petani sawit yang sukses. Tentu mereka memiliki penghasilan yang lebih jika dibandingkan dengan hanya menjadi nelayan.

Apabila masyarakat hanya bertumpu pada perekonomian di laut saja, yakni hanya bermata pencaharian sebagai nelayan, menjadikan masyarakat akan hidup pas- pasan, hanya cukup untuk mencukupi kebutuhan sehari-hari, bahkan lebih mirisnya untuk kebutuhan pangan saja tidak tercukupi. Kehidupan melaut sangat tergantung pada kondisi alam, apabila cuaca buruk, badai, dan ombak besar, maka otomatis nelayan tidak bisa pergi melaut sampai keadaan alam memang sudah kondusif dan baik. Kondisi seperti ini sering kali terjadi, maka untuk mengantisipasi anjloknya perekonomian rumah tangga nelayan, mereka menjadikan pertanian dan peternakan sebagai lahan utama untuk melanjutkan penghidupan, dibandingkan dengan menjadi seorang nelayan. Walaupun dalam keseharian mereka tinggal di daerah tepi pantai dan akrab sekali dengan laut.

Tabel 1. Mata Pencaharian Penduduk Nagari Airhaji Tahun 2011.

\begin{tabular}{|l|l|c|c|}
\hline No & \multicolumn{1}{|c|}{$\begin{array}{c}\text { Mata } \\
\text { Pencaharian }\end{array}$} & Persentase & $\begin{array}{c}\text { Jumla } \\
\text { h }\end{array}$ \\
\hline 1 & Petani & 33 & 4.903 \\
\hline 2 & Nelayan & 24 & 3.566 \\
\hline 3 & $\begin{array}{l}\text { Pedagang dan } \\
\text { Wiraswasta }\end{array}$ & 19 & 2.826 \\
\hline 4 & $\begin{array}{l}\text { PNS/ABRI/POL } \\
\text { RI }\end{array}$ & 14 & 2.080 \\
\hline 5 & Pensiunan & 8 & 1.188 \\
\hline 6 & Dan Lain-Lain & 2 & 14860 \\
\hline & Jumlah & 100 & $\begin{array}{c}14.86 \\
0\end{array}$ \\
\hline
\end{tabular}

Sumber: Badan Pusat Statistik. "Profil Nagari Airhaji Tahun 2011". Kecamatan Linggo Sari Baganti: BPS Tahun 2011".

Mata pencaharian masyarakat Airhaji beraneka ragam dan jumlah penduduk yang bekerja sebagai petani adalah yang paling banyak, yakni 33\% dari 14.860 tenaga produktif yang ada dan selebihnya sebagai nelayan, pegawai, pedagang, pensiunan, dan lain-lain (BPS,2011). Pertanian merupakan sumber mata pencaharian utama Nagari Airhaji, karena di negeri ini banyak terdapat lahan kosong yang dapat digunakan sebagai lokasi pertanian. Tanah yang subur karena berbatasan langsung dengan bukit Barisan, membuat perkembangan usaha masyarakat pada sektor kehutanan dan perkebunan dari tahun 2000 mengalami peningkatan yang 
tajam, hal ini terlihat dengan antusiasnya masyarakat menanam komoditi yang memiliki prospek pemasaran menguntungkan, seperti komoditi karet, kelapa sawit dan coklat. Melihat perkembangan ini produksi kehutanan dan perkebunan di Nagari Airhaji akan menjadi tumpuan masyarakat dalam meningkatkan kesejahteraannya.

\section{Nelayan Juragan di Nagari Airhaji}

Masyarakat pesisir didefinisikan sebagai kelompok orang yang tinggal di daerah pesisir dan sumber kehidupan perekonomiannya bergantung secara langsung pada pemanfaatan sumberdaya laut dan pesisir. Definisi inipun bisa juga dikembangkan lebih jauh karena pada dasarnya banyak orang yang hidupnya bergantung pada sumberdaya laut. Mereka terdiri dari nelayan pemilik, buruh nelayan, pedagang ikan, pengolah ikan, pembudidaya ikan dan organisme laut lainnya (Lucky Zamzami,2007).

Semua orang yang bekerja di sektor kelautan dengan memanfaatkan hasil laut sebagai perekonomian dinamakan dengan nelayan. Namun, dalam pembagian wilayah kerja, nelayan dapat dikategorikan menjadi nelayan pemilik dan nelayan buruh (Arif Satria,2002). Nelayan pemilik atau juragan adalah orang yang memiliki sarana perlengkapan ikan seperti perahu, jaring dan alat tangkap lainnya. Sementara nelayan buruh adalah orang yang menjual jasa tenaga kerja sebagai buruh dalam kegiatan penangkapan ikan di laut, atau sering disebut dengan anak bagan atau anak buah kapal.

Nelayan dibagi menjadi beberapa macam status nelayan. Pertama, nelayan juragan, merupakan nelayan yang mempunyai kapal sehingga mempekerjakan kapal nelayan lain sebagai buruh tanpa ia harus bekerja. Meskipun demikian, ada juga di antara juragan yang juga ikut melaut bersamasama dengan awak kapal. Kedua, nelayan sedang, nelayan yang kebutuhan hidupnya dapat ditutup dengan pendapatan pokoknya dari bekerja sebagai nelayan, dan memiliki perahu dan hanya mempekerjakan keluarga dekat saja. Ketiga, nelayan miskin, merupakan nelayan yang pendapatan dari perahunya tidak mencukupi kebutuhan hidupnya sehingga harus ditambah dengan bekerja lain, baik untuk ia sendiri atau untuk istri dan anak-anaknya. Keempat, buruh nelayan yaitu bekas nelayan yang pekerjaannya memperbaiki jaring yang sudah rusak. Pekerjaan ini biasanya dilakukan oleh kelompok orang-orang miskin yang berusia diatas 40 tahun dan sudah tidak kuat lagi melaut.

Seorang juragan yang memiliki alat tangkap canggih dan kapal milik sendiri sebagai pemilik modal merupakan induk semang yang memiliki kedudukan tertinggi dalam stratifikasi sosial masyarakat nelayan. Didaulat telah memiliki pengalaman dalam usaha perikanan. Pengalaman melaut yang dimiliki oleh juragan yang kemudian menjadikannya sebagai pelaut ulung. Betapa tidak, walaupun telah menjadi juragan ia juga ikut melaut dengan kapal miliknya sendiri. Hal ini menandakan bahwa walaupun telah menjadi induk semang, juragan juga ikut merasakan getirnya kehidupan seorang nelayan di kala melaut di tengah laut lepas. Namun, ada juga juragan yang hanya menunggu kapalnya pulang melaut tanpa banyak turut ikut campur. Semua urusan di dalam laut dipercayakan kepada tungganai yang dianggap telah mempunyai kemampuan dan dipercaya mengurus semua keperluan yang dibutuhkan.

Adanya kapal bagan telah mempengaruhi keberlangsungan hidup masyarakat. Begitu juga dengan persepsi masyarakat yang mengatakan bahwa pekerjaan nelayan dipilih karena dipandang lebih baik dan lebih mudah untuk mendapatkan hasil. Apalagi menjadi seorang anak bagan, mereka hanya berbekal pancing, itupun hasil tangkapan yang didapatkan akan menjadi milik pribadi tanpa melibatkan juragan. Sementara itu, kebutuhan utama 
ketika melaut seperti bahan makanan, bahan bakar, rokok, kopi, piber, dan batu es selama melaut. Semuanya dapat ditanggulangi oleh juragan.

Jumlah pemilik bagan yang tersebar di Nagari Airhaji berjumlah 12 orang dengan jumlah bagan sebanyak 15 unit. Keberadaan alat-alat penangkapan yang modern tersebut menjadikan masyarakat dapat menangkap ikan lebih banyak lagi dan waktu yang diperoleh dari hasil penangkapan ikan relatif kecil. Dengan semakin berkembangnya bagan sebagai teknologi penangkapan ikan yang canggih, maka masyarakat nelayan lokal dituntut untuk dapat mengembangkan teknologi perikanan yang lebih baik lagi.

Tanpa bisa dipungkiri bahwa kehadiran bagan di tengah-tengah kehidupan masyarakat telah membuka lapangan pekerjaan, terutama bagi masyarakat yang tidak mempunyai bekal ijazah. Kehidupan nelayan tidak menuntut nilai akademis, karena hanya dengan bekal kemauan dan bersungguh-sungguh terhadap pekerjaan, seorang juragan akan mempekerjakannya pada kapal milik juragan tersebut.

Tabel 2. Nama-nama Juragan Pemilik bagan di nagari Airhaji Tahun 2016

\begin{tabular}{|l|l|l|l|}
\hline No & Nama Pemilik & $\begin{array}{l}\text { Nama } \\
\text { Kapal }\end{array}$ & $\begin{array}{l}\text { Bobot } \\
\text { Kapal (GT) }\end{array}$ \\
\hline 1 & $\begin{array}{l}\text { Dedi } \\
\text { Suhendra/Idet }\end{array}$ & $\begin{array}{l}\text { KM. Putri } \\
\text { Bungsu }\end{array}$ & 30 \\
\hline 2 & $\begin{array}{l}\text { Bahtiar/Ajo } \\
\text { Tiar }\end{array}$ & $\begin{array}{l}\text { KM. Setia } \\
\text { Murni 010 }\end{array}$ & 28 \\
\hline 3 & Yulianti/Andi & $\begin{array}{l}\text { KM. Setia } \\
\text { Murni 011 }\end{array}$ & 30 \\
\hline 4 & $\begin{array}{l}\text { Zainal } \\
\text { Arifin/Inal PI }\end{array}$ & $\begin{array}{l}\text { KM. Pantai } \\
\text { Indah 02 }\end{array}$ & 42 \\
\hline 5 & Siil & $\begin{array}{l}\text { KM. } \\
\text { Semangat } \\
\text { Samudera }\end{array}$ & 12 \\
\hline 6 & Adrizel/Izel & KM. Lepi & 23 \\
\hline 7 & Wik & KM & 12 \\
\hline 8 & Epi & $\begin{array}{l}\text { KM. } 86 \\
\text { Intan }\end{array}$ & 37 \\
\hline 9 & Arkam & KM. Regin & 18 \\
\hline 9 & Waldi & $\begin{array}{l}\text { KM. Putri } \\
\text { Tunggal 04 }\end{array}$ & 30 \\
\hline 10 & Waldi & $\begin{array}{l}\text { KM. Kurnia } \\
\text { Abadi 01 }\end{array}$ & 28 \\
\hline 11 & Ipun & KM. Wendi & 30 \\
\hline & & \multicolumn{2}{|l|}{} \\
\hline
\end{tabular}

\begin{tabular}{|l|l|l|l|}
\hline & & 03 & \\
\hline 12 & Ipun & $\begin{array}{l}\text { KM. Karya } \\
\text { Samudera }\end{array}$ & 22 \\
\hline 13 & Indrianto & $\begin{array}{l}\text { KM. } \\
\text { Permata } \\
\text { Bunda }\end{array}$ & 17 \\
\hline 14 & $\begin{array}{l}\text { Muhammad } \\
\text { Dia }\end{array}$ & $\begin{array}{l}\text { KM. } \\
\text { Pergaulan } \\
01\end{array}$ & 17 \\
\hline 15 & $\begin{array}{l}\text { Muhammad } \\
\text { Dia }\end{array}$ & $\begin{array}{l}\text { KM. } \\
\text { Pergaulan }\end{array}$ & 12 \\
\hline
\end{tabular}

Sumber: Aswardi Bakar. Data-Data di Nagari Airhaji. Penyuluh Perikanan Kecamatan Linggo Sari Baganti Airhaji. Dokumen 2016.

Ternyata, dibalik potensi laut yang luar biasa kayanya, yang telah dimanfaatkan secara bijak oleh para juragan kapal, tersimpan berbagai persoalan dan lika-liku kehidupan yang dilematis. Perekonomian dengan hanya bertumpu pada hasil laut saja tidaklah selalu berjalan mulus. Rezeki yang didapatkan hanyalah berupa "rezeki harimau". Yakni, penghasilan yang didapatkan tidak selalu dengan angka yang pasti, cenderung tidak menentu. Terkadang pulang dengan membawa setumpuk uang. Ibarat mampu untuk membeli seekor kambing hanya dengan beberapa hari bekerja. Akan tetapi, tidak jarang nelayan pulang dengan tangan kosong, tanpa penghasilan sepeser pun juga.

Uniknya, para nelayan bisa beristirahat untuk pergi ke laut hingga bermingguminggu lamanya. Artinya, nelayan kalau sudah mendapatkan rezeki yang dirasa cukup, mereka senantiasa tidak akan bekerja untuk beberapa hari kedepannya sampai penghasilan yang diperolehnya akan habis. Ibaratnya, "bila sudah kenyang langsung tidur". Setelah bahan dapur untuk dimasak tidak ada dan uang ditangan telah menipis, barulah mereka akan berpikir kembali untuk bekerja. Hal ini menggambarkan bahwa, nelayan tidak memanfaatkan dengan bijak rezeki yang didapatkan. Mereka senantiasa akan menghambur-hamburkan uang yang didapatkan tanpa diketahui kebermanfaatannya. Inilah salah satu penyebab yang mengakibatkan mudahnya 
harta yang didapatkan akan hilang sekejap mata. Selain faktor alam ketika melaut yang sedang tidak bersahabat, sehingga beresiko terhadap tenggelamnya kapal milik nelayan, kebiasaan hidup nelayan juga menjadi faktor yang menjadi penyebab mudah hilangnya harta benda yang telah didapatkan. Sementara itu, mereka tidak menyadari bahwa, bukan saja harta yang telah dimiliki dapat musnah seketika, pertaruhan nyawa selama di dalam laut bisa saja dialami oleh seorang nelayan (Rohmin Dahuri,2004).

Resiko untuk membuka sebuah usaha yang berbasis kelautan memang tinggi. Terbukti, ketika cuaca buruk, ombak besar, seketika itulah malapetaka dapat menghampiri siapa saja yang masih mencari penghidupan di laut. Tanpa bisa mengelak, kapal yang selama ini telah menjadi sumber mata pencaharian dapat hancur seketika tanpa sisa. Harapan nelayan seakan pupus bersamaan dengan karamnya kapal sebagai tonggak perekonomian. Tetapi, peristiwa ini telah menjadi hal yang biasa di tengahtengah kehidupan juragan kapal. Tanpa kenal lelah dan putus asa, pemilik kapal berusaha ikhlas atas kejadian yang tengah menimpanya. Pada akhirnya kesabaran lah yang mampu untuk mengobatinya. Mental baja dan semangat juang yang tinggi telah menjadi jati diri sang juragan. Kondisi apapun yang telah menimpanya, ia akan tetap berusaha tegar dan mengatur strategi kembali untuk membangkitkan usaha yang tengah dirintisnya dari belasan tahun yang lalu.

\section{Hubungan Kerja Antara Juragan dan Anak Bagan}

Seperti yang umum dijumpai pada masyarakat nelayan yang berada di kawasan pesisir, masyarakat nelayan di Nagari Airhaji khususnya, hubungan antara juragan dan anak bagan (buruh dan pemilik) mempunyai ikatan yang "spesial", sangat berbeda dengan hubungan antara buruh dan pemilik di perusahaan atau industri pada umumnya. Hubungan antara pemilik dan buruh nelayan bersifat patronklien, yakni hubungan saling ketergantungan yang kedua belah pihak saling membutuhkan. Seperti apa yang telah dikemukakan oleh Scott, dalam hubungan ini pihak pemilik modal yakni juragan selaku pemilik bagan bertindak sebagai patron, memberikan berbagai bantuan kepada anak buahnya dalam hal ini anak bagan (Rilus A Kinseng,2011). Sedangkan yang bertindak sebagai klien adalah pekerja, yakni anak bagan yang berstatus sebagai anak buah pada sebuah kapal milik juragan.

Para patron ini memiliki status dan peranan sosial yang penting dalam kehidupan masyarakat. Anak buah yang telah diberikan bantuan oleh induk semang akan membalas kebaikan tersebut dengan kesiapan menyediakan jasa tenaganya untuk membantu juragan atau patron. Aktualisasi relasi patron-klien ini merupakan upaya menjaga kerukunan bersama, sehingga efek negatif kesenjangan sosial di kalangan masyarakat nelayan dapat diminimalisasi (Kusnadi,2000).

Secara intensif, relasi patron-klien ini terjadi didalam aktivitas pranata ekonomi dan kehidupan sosial masyarakat yang tinggal di daerah. Bantuan dari juragan kepada anak buahnya mencakup berbagai bentuk seperti meminjamkan uang, membayar biaya pengobatan, memberi ongkos untuk pulang kampung, membayar biaya perkawinan, serta berbagai kebutuhan yang mendesak lainnya. Sehingga, juragan seolah-olah telah menjadi penyelamat dan tempat mengadu dikala masalah kesulitan ekonomi melanda anak bagan.

Pada satu pihak, hubungan antara pemilik dan buruh nelayan tersebut mengandung unsur eksploitasi dan dominasi. Tetapi, sifatnya masih berbeda dengan eksploitasi dan dominasi hubungan yang bukan patronklien. Eksploitasi dan dominasi dalam pola hubungan pola patron-klien lebih halus, dapat terlihat namun tidak dirasakan oleh klien. Semua itu dapat tertutupi dengan pemberian bantuan oleh patron atau 
juragan kepada klien atau anak bagan dirasakan jauh lebih besar.

Gambar 1. Aktivitas Nelayan di Muara Tanjung Kadis Airhaji Tahun 2016.

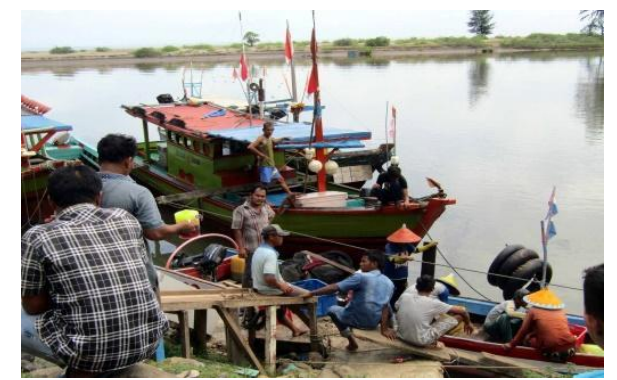

Sumber: Dokumentasi Aswardi Bakar Penyuluh Perikanan Kecamatan Linggo Sari Baganti.

Unsur eksploitasi dapat terlihat pada siklus kerja yang diatur semuanya oleh juragan. Para buruh nelayan umumnya tidak mempunyai kontrol terhadap kegiatan produksi. Mereka bekerja di bawah kontrol komando sang pemilik atau yang mewakilinya (nakhoda). Pada saat dilakukan pembagian keuangan, si pemilik ataupun juragan tidak menjelaskan secara terbuka dan rinci berapa jumlah seluruh biaya operasi yang dikeluarkan dan berapa jumlah penghasilan seluruhnya. Juragan sebagai pemilik modal hanya membagikan uang kepada masing-masing anak buah. Biasanya, dalam sistem bagi hasil, anak bagan umumnya hanya menerima. Mereka seolah tidak ada hak untuk memprotes dan menggugat pembagian sistem keuangan yang berlaku. Jika hasil tangkap melaut sedikit atau bahkan tidak ada, maka tak jarang anak bagan pulang dengan tangan kosong.

Dalam satu bulan, efisien nelayan bisa melaut adalah selama 15 hari. Untuk 15 hari ke depan mereka biasanya makan di warung dengan cara mengutang dan dibayar duluan oleh induk semang. Hal ini sebetulnya sama dengan hutang yang nantinya harus dibayar dengan memotong pemasukan dari nelayan tersebut. Namun, tiada daya karena selain menawarkan jasa dan tenaga, anak bagan memang tidak punya modal sedikitpun selama melaut. Bekal logistik melaut 3-7 hari bahkan lebih dan bagan sebagai prasarana, semuanya dimodali dan ditanggung oleh juragan. Maka, dengan tidak ada pilihan lain, maka buruh nelayan atau anak bagan pasrah dengan pembagian hasil yang tidak seberapa dibandingkan sang juragan sebagai pemilik modal.

Jumlah pekerja dalam satu buah bagan berjumlah 10-15 orang. Masing-masing anak bagan mendapatkan pembagian kerja yang jelas dari tungganai. Jika dalam laut mereka dipimpin oleh seorang nakhoda kapal yang disebut dengan tungganai. Tungganai mempunyai tanggung jawab terhadap semua anggota dan berhak untuk mengatur semua proses penangkapan ikan di laut. Anak bagan wajib untuk mematuhi semua perkataan dari tungganai. Tungganai dibantu dengan seorang asisten yang disebut dengan kuanca, yang mempunyai tanggung jawab terhadap semua kerusakan pada bagian mesin. Selebihnya adalah Anak Buah Kapal (ABK) atau anak bagan dan anak kayia. Biasanya anggota tetap atau anak bagan berjumlah 6 orang dan anak kayia berjumlah 6 orang. Perbedaan ABK dengan anak kayia hanyalah pada upah yang diberikan. Seorang ABK mendapatkan upah dari pemilik bagan berupa bagian dari hasil tangkapan yang didapatkan selama melaut. Sementara anak kayia hanyalah menumpang melaut dan hanya berharap pada hasil pancingan sendiri, walaupun induk semang berbaik hati jika hasil tangkapan sedang banyak, anak kayia akan mendapatkan uang yang biasa disebut "uang ampera" kurang lebih sekitaran 50 - 100 ribu rupiah.

Tabel 3. Rata-rata Pendapatan Nelayan Perbulan di Tahun 2015.

\begin{tabular}{|c|c|c|c|}
\hline No & Nilai & \multicolumn{2}{|c|}{ Pendapatan Bersih Nelayan } \\
\cline { 3 - 4 } & & $\begin{array}{c}\text { Juragan } \\
\text { (Rp) }\end{array}$ & $\begin{array}{c}\text { Anak Bagan } \\
\text { (Buruh } \\
\text { Nelayan (Rp) }\end{array}$ \\
\hline 1 & Tertinggi & 30.000 .000 & 3.000 .000 \\
\hline 2 & Terendah & 5.000 .000 & 1.500 .000 \\
\hline
\end{tabular}


Sumber: Diolah dari Data Penyuluh Perikanan Dinas Kelautan dan Perikanan Kabupaten Pesisir Selatan.

Telah dapat dipastikan bahwa pendapatan nelayan juragan akan lebih besar dari pada anak bagan ataupun nelayan buruh lainnya. Betapa tidak, semua modal melaut ditanggulangi oleh juragan. Sementara itu, anak bagan hanya menyumbangkan tenaga dalam pengoperasian kapal ketika melaut. Seakan telah terjerat oleh sistem pembagian upah yang tidak setara dengan penghasilan yang didapatkan, anak bagan hanya pasrah karena ketiadaan modal. Umpamanya keuntungan hasil tangkapan sekali melaut mencapai 30 juta rupiah. Pertama-tama, uang tersebut harus dikeluarkan untuk menutupi biaya bekal ketika melaut yang sebelumnya ditanggulangi oleh juragan. Bekal tersebut merupakan persediaan utama yang harus tercukupi selama melaut, seperti bahan bakar, beras, lauk pauk, rokok, kopi, piber, dan es batang. Apabila bekal mencapai 15 juta rupiah, maka sisanya 15 juta lainnya dibagi lagi menjadi dua. Yakni 7,5 juta rupiah pembagian untuk induk semang. Kemudian, 7,5 juta lainnya, dibagi sebanyak anggota yang ikut melaut. Misalnya ABK semuanya berjumlah 15 orang, maka mereka akan mendapatkan gaji sebesar 500 ribu per orangnya.

Ketimpangan dalam sistem bagi hasil seperti ini nampaknya sudah menjadi tradisi atau budaya dalam kehidupan masyarakat nelayan dan nampaknya kondisi seperti ini cenderung dilestarikan oleh nelayan pemilik modal atau juragan yang mendominasi para nelayan. Sementara nelayan buruh atau anak bagan tidak mempunyai pilihan. Selain karena keterbatasan modal, nelayan buruh atau anak bagan juga dilanda keahlian dan keterampilan yang tidak memadai. Ketimpangan ini terjadi karena patron berada dalam posisi pemberi barang dan jasa yang sangat dibutuhkan oleh si klien beserta keluarganya agar mereka bisa tetap hidup. Rasa wajib membalas pada diri si klien muncul lewat pemberian ini. Selama pemberian tersebut masih dirasakan mampu memenuhi kebutuhannya yang paling pokok atau yang diperlukan (M.Firza,2000).

Nelayan kelas bawah atau anak bagan hidupnya sangat rentan akan kemiskinan karena penghasilannya dari penangkapan ikan hanya cukup untuk memenuhi kebutuhan hidup sehari-hari bersama keluarganya. Hasil tangkapan yang sangat sedikit atau bahkan tidak mendapatkan hasil tangkapan dalam satu hari bisa membuatnya tidak mampu membeli kebutuhan hidup hari itu juga. Keharusan untuk tetap melanjutkan kehidupan akan terpaksa membuatnya untuk mencari alternatif pinjaman. Tentu keadaan seperti ini yang tidak bisa melepaskan seorang anak bagan untuk tidak bergantung kepada juragan (Sufirudin,2016). Di sinilah akan muncul hubungan antara juragan dan anak bagan dalam bentuk hubungan saling ketergantungan. Anak bagan atau pun nelayan buruh yang melakukan transaksi pinjam-meminjam (berhutang) kepada juragan, merupakan hal yang biasa terjadi dalam kehidupan masyarakat nelayan. Didukung dengan adanya rasa kepercayaan yang dimiliki oleh nelayan juragan kepada anak bagan, yang selama telah mengabdikan diri bekerja dengannya.

Didorong oleh unsur balas jasa, seorang anak bagan jarang sekali untuk menolak apa yang dikatakan oleh juragan. Jika sang juragan mengatakan melaut, maka dengan tidak ada pilihan bagi anak bagan untuk tidak mengikutinya. Kecuali, ada kondisi tertentu yang memang mengharuskan anak bagan untuk tidak bisa melaut. Seperti sedang sakit, ada keluarga yang meninggal atau pesta hajatan, dan lain sebagainya. Buruh nelayan yang dianggap malas bekerja atau tidak pergi melaut tanpa alasan yang jelas, maka dengan tidak segan-segan sang juragan akan memperingati bahkan memberhentikan apabila tidak mengindahkan perkataan juragan. Ini disebabkan oleh beberapa faktor yang mengharuskan juragan harus berperilaku 
seperti itu, salah satunya watak masyarakat pesisir pantai yang sedikit keras, maka untuk memperingatinya pun harus dengan cara yang agak sedikit kasar dan keras juga. Dengan demikian, pola hubungan antara juragan dan anak bagan ini mempunyai dua dimensi, yakni dimensi yang bersifat eksploitatif ketika buruh mengalami eksploitasi dan dominasi dari pihak pemilik bagan, dan dimensi patron-klien ketika para buruh mendapatkan berbagai bantuan dari sipemodal dalam hal ini juragan pemilik bagan.

Dalam perekrutan anak bagan menjadi tanggung jawab seorang tungganai atau kapten kapal. Anak bagan yang telah bekerja pada kapal juragan merupakan rekrutan yang bersifat tidak permanen dan tanpa perjanjian secara tertulis. Artinya anak bagan dapat berpindah ke kapal lain sewaktu-waktu. Tetapi, mereka cenderung tidak berpindah, karena telah diikat dengan kedekatan hubungan emosional yang begitu erat. Meskipun begitu, adapun anak bagan yang memutuskan untuk berpindah juragan, sama sekali tidak menjadi persoalan yang berarti bagi juragan sebelumnya. Bukan saja hubungan yang harmonis terjalin antar sesama anak bagan saja, tetapi antara juragan pemilik kapal juga senantiasa menjalin hubungan keakraban. Rasa kebersamaan mereka diikat oleh satu daerah asal, satu tempat tinggal dan satu mata pencaharian. Adanya ikatan tersebut, maka hubungan yang terjalin antar sesama nelayan juragan dapat dikatakan berupa hubungan persaudaraan. Terkadang, ketika kapal bagan yang biasa ditumpangi oleh seorang anak bagan dalam keadaan rusak, otomatis tidak pergi melaut. Anak bagan akan pergi melaut bersama kapal bagan milik juragan lain, sampai kapal yang biasa ditumpanginya tersebut selesai diperbaiki. Hal ini sudah biasa terjadi. Juragan akan senantiasa dapat mengerti dan memahaminya, karena apabila anak bagan tidak bekerja, dengan apa ia akan menghidupi keluarganya.
Pada umumnya di Nagari Airhaji biasanya seorang anak bagan itu sendiri yang akan menjumpai tungganai untuk melakukan perjanjian keikutsertaan dalam melaut. Seorang anak bagan akan melihat dulu siapa tunggangannya. Anak bagan akan melihat dan menilai tungganai berdasarkan pengalaman melautnya. Semakin berpengalaman seorang tungganai maka semakin banyak pula anak bagan yang ingin ikut serta dengannya. Hal ini dipengaruhi oleh asumsi anak bagan yang menganggap bahwa, jika seorang tungganai memiliki lebih banyak pengalaman melaut, maka tungganai tersebut lebih mengetahui wilayah-wilayah laut yang berpotensi menghasilkan tangkapan yang banyak. Dengan demikian, ini akan mempengaruhi besaran upah yang akan diterimanya nanti.

Para nelayan yang sudah berkeluarga, alasan utama mereka bekerja sebagai nelayan adalah karena mereka tidak mempunyai keterampilan lain. Lahan atau pun tanah untuk bertani terbatas. Menurut mereka untuk menjadi seorang nelayan tidak terlalu sulit, maka pilihan hidup untuk memutuskan bekerja sebagai nelayan adalah takdir yang harus dijalani. Upayaupaya yang dilakukan oleh nelayan untuk bisa bekerja pada sebuah kapal milik juragan adalah dengan menjalin hubungan baik dengan para nelayan lainnya dan dengan para tungganai. Seorang tungganai mencari anak buah kapal bukan karena hubungan keluarga, tetapi berdasarkan kemampuan dan keuletan anak buah kapal tersebut (Syahrizal,Sri Meiyenti dan Rinaldi Ekaputra,2011)

Apabila ditelusuri lebih mendalam, sebenarnya pola hubungan antara juragan dan anak buahnya adalah berbentuk pola binaan. Pembinaan berarti upaya untuk melakukan perubahan sikap mental, perubahan cara beroperasi. Mempelajari, memahami kondisi lingkungan dari setiap badan usaha kecil dan menengah, untuk bisa naik tingkat menjadi pengusaha berkelas juragan (Amir MS 2007). Akan tetapi, tidak semua anak buah yang dibina dan diberikan 
pinjaman modal oleh juragan. Salah satunya adalah anak buah yang memang memiliki hubungan emosional yang baik dengan juragan, namun selain itu anak buah yang mendapatkan binaan dari juragan adalah saudara atau karib kerabatnya sendiri. Misalnya, mereka diikat oleh hubungan kakak beradik, hubungan sasuku, ataupun hubungan kesamaan daerah asal.

Hal tersebut terlihat pada kehidupan Icap yang pada awalnya hanyalah berstatus anak buah pada kapal milik saudara kandungnya yang bernama Ijap. Pada tahun 1999, awal mula Icap bekerja di sektor kelautan dan berstatus sebagai tungganai. Walaupun, kapal yang dinahkodai merupakan kapal milik saudara kandungnya, tidak menjadikannya merasa berkuasa atas kapal tersebut. Ia tetap bekerja di bawah komando dan atas perintah induk semangnya yakni juragan Ijap. Namun, di sisi lain Ijap yang merupakan kakak kandung dari Icap yang sekaligus sebagai induk semang, merasa berkewajiban untuk membantu perekonomian keluarganya yang lain. Terutama keluarga yang memiliki hubungan tali darah dengannya. Selain semangat dan kerja keras dari Icap, pada tahun 2015 ia mampu untuk membeli satu unit kapal boat atas nama pribadi. Setelah puluhan tahun bekerja pada kapal milik saudaranya, akhirnya ia mampu untuk membuka usaha kepunyaan sendiri dan memiliki beberapa orang pekerja dalam pengoperasian kapal miliknya tersebut. Tentu dengan apa yang telah dicapai tidak terlepas dari bantuan dan dorongan Ijap selaku saudara kandung yang sekaligus induk semang.

Hubungan kerja yang terjalin baik antara juragan dengan buruh maupun antara tungganai dengan buruh, tercipta hubungan yang lebih bersifat kekeluargaan, di mana hubungan ini dapat berjalan senyaman mungkin tidak bersifat kaku. Masyarakat nelayan secara umum memiliki pola interaksi yang sangat mendalam, pola interaksi yang dimaksud dapat dilihat dari hubungan kerjasama dalam melaksanakan aktivitas, melaksanakan kontak secara bersama baik antara nelayan dengan nelayan maupun dengan masyarakat lainnya. Mereka memiliki tujuan yang jelas dalam melaksanakan usahanya serta dilakukan dengan sistem yang permanen, sesuai dengan kebudayaan pada masyarakat nelayan.

Jaringan kerja antara juragan dan anak bagan diibaratkan dengan "jaring laba-laba" yang saling berkaitan. Jaring yang terkonsentrasi untuk melakukan kerjasama antar individu dan kelompok yang membentuk norma saling percaya dalam melakukan pekerjaan menangkap ikan di laut. Mereka memiliki satu tujuan, yakni mendapatkan hasil tangkapan semaksimal dan sebanyak-banyaknya, sehingga mampu untuk memasarkan ikan tangkapan ke berbagai daerah. Secara tidak langsung, kegiatan perekonomian seperti ini telah mampu untuk meningkatkan ekonomi masyarakat pesisir yang memanfaatkan ekosistem laut sebagai sumber daya yang isinya mempunyai nilai ekonomi.

\section{KESIMPULAN DAN IMPLIKASI}

\section{Kesimpulan}

Orang yang bekerja di laut dengan menggunakan sarana alat tangkap semuanya disebut sebagai nelayan. Namun, dalam penerapan sistem kerja dan pelaksanaannya terdapat pembagian stratifikasi yang begitu kentara. Pemilik bagan atau kapal bertindak sebagai juragan yang biasa disebut induk semang, dalam hal ini berada pada stratifikasi paling atas. Sedangkan anak bagan yang merupakan anak buah si pemilik kapal berada pada tingkatan paling bawah, dengan pembagian upah yang tidak sebanding dengan induk semang.

Bekal beserta alat tangkap laut yang tidak murah, menjadikan anak bagan pasrah dengan keadaan. Betapa tidak, semua ini hanya bisa dipenuhi oleh pemodal yakni 
pemilik bagan sebagai induk semang. Kebutuhan perekonomian yang kian terus meningkat, tidak ada pilihan bagi anak bagan untuk tidak mengikuti jalan perekonomian dari sang juragan. Sehingga menjadikan anak bagan hidup dalam taraf ekonomi ke bawah dan miskin yang berbeda jauh dengan pemilik bagan yang hidup berkecukupan dan tergolong kaya.

Ketimpangan seperti ini sudah biasa saja terjadi, baik juragan maupun anak tidak merasa terintimidasi dan mengintimidasi dengan alur kerja seperti itu, karena mereka telah di daerah oleh prinsip-prinsip relasi patron-klien. Unsur-unsur sosial yang berpotensi sebagai patron adalah juragan yang merupakan nelayan pemilik modal, sedangkan klien adalah nelayan buruh, pekerja ataupun anak buah dari juragan. Kehadiran patron ini memiliki status dan peranan sosial yang penting dalam kehidupan masyarakat nelayan, karena patron "bak dewa penyelamat" bagi seorang klien ketika kesusahan datang melanda. Oleh karena itu, dengan segala bentuk dominasi dan diskriminasi yang dilakukan oleh juragan secara konkrit tidak di rasa oleh klien dan telah tertutupi dengan bantuan yang diberikan oleh juragan tersebut.

Namun, dibalik itu semua ada hubungan kekerabatan yang nyata terjalin antara sesama nelayan. Yakni, hubungan antara juragan dan anak bagan. Relasi patron-klien antara juragan dan anak bagan yang telah meminimalisir terjadinya bentrokan dan meredam konflik yang sewaktu-waktu bisa terjadi antara sesama nelayan. Nelayan yang telah ditolong oleh seorang juragan akan membalas kebaikan tersebut dengan kesiapan menyediakan jasa tenaga. Aktualisasi relasi patron-klien ini merupakan upaya menjaga kerukunan bersama, sehingga efek negatif kesenjangan sosial di kalangan masyarakat nelayan dapat diminimalisasi.

\section{Implikasi}

Apabila ditelusuri lebih mendalam, ternyata hubungan antara juragan dan anak buahnya menerapkan pola binaan. Namun, tidak semua anak buah yang mendapatkan perlakuan binaan oleh juragan. Pola binaan diterapkan bagi anak buah yang memang mempunyai hubungan kekerabatan dan persaudaraan dengan juragan. Misalnya, saudara kandung, saudara sasuku, anak kandung, serta para kerabat yang mempunyai hubungan kekerabatan dengan juragan. Pola binaan ini merupakan salah satu upaya yang dilakukan oleh juragan untuk membantu perekonomian baik keluarga dekat maupun anak buah yang memang memiliki hubungan emosional yang baik dengan juragan. Mereka dipercayakan oleh juragan untuk mengelola usahanya. Hal ini bertujuan sebagai pengetahuan untuk anak buahnya supaya bisa belajar untuk berdiri sendiri membuka usaha perikanan sama seperti apa yang dilakukan oleh juragan.

\section{DAFTAR PUSTAKA}

AB. Lapian. 2008. Pelayaran dan Perniagaan Nusantara Abad ke-16 dan 17. Jakarta: Komunitas Bambu.

2011. Orang Laut Bajak Laut Raja Laut, Jakarta: Komunitas Bambu.

Abd Rahman Hamid. 2015. Sejarah Maritim Indonesia.Yogyakarta: Ombak.

Arif Satria. 2002. Pengantar Sosiologi Masyarakat Pesisir. Jakarta: Cidesindo.

Badan Pusat Statistik.2011 Kecamatan Linggo Sari Baganti dalam Angka Tahun 2011, BPS Kec. Linggo Sari Baganti Pesisir Selatan

Benda-Beckman, Keebet Von. 2000. Goyahnya Tangga Menuju Mufakat. Jakarta: Grasindo.

Cortesao, Armando. 2014. Suma Oriental Karya Tome Pires: Perjalanan dari Laut Merah ke Cina dan Buku Fransisco Rodriques. Yogyakarta: Ombak. 
Djoko Pramono. 2005. Budaya Bahari. Jakarta: PT Gramedia Pustaka Utama.

Gusti Asnan. 2007. Dunia Maritim Pantai Barat Sumatera. Yogyakarta: Ombak. . 2016. Sungai dan Sejarah Sumatera. Yogyakarta: Ombak.

Haslim BA. 1997. Pesisir Selatan Membangun. Painan: Kantor Deppen Kabupaten Pesisir Selatan

Helius Sjamsudin. 2012. Metodologi Sejarah. Yogayakarta: Ombak.

Jopie Wangania. 1980. Jenis-Jenis Perahu di Pantai Utara Jawa-Madura. Jakarta: Direktorat Jenderal Kebudayaan Departemen Pendidikan dan Kebudayaan.

Jumhari, "Melacak Kearifan Tradisional dan Alih Pengetahuan Teknologi Pembuatan Kapal Tradisional di Daerah Air Haji Lewat Tuturan Si Tukang Tuo Bagan", Jurnal Suluah Vo.15 No.19.

Kusnadi. 2009. Keberdayaan Nelayan dan Dinamika Ekonomi Pesisir. Yogyakarta: Ar Ruzz Media. - 2009. Ekologi Politik Nelayan. Yogyakarta: LKiS.

Nur, Mhd. 2000. Bandar Sibolga di Pantai Barat Sumatera pada Abad ke 19 Sampai Pertengahan Abad ke-20. Disertasi. Jakarta: Universitas Indonesia.

Purniati, Nina. 2014. Konflik Nelayan di Kecamatan Linggo Sari Baganti dan Pancung Soal Kabupaten Pesisir Selatan, Studi Kasus: Air Haji Tanjung Kandis dan Pulau Rajo Inderapura. Skripsi. Padang: STKIP PGRI Sumatera Barat.

Rahardjo Adisasmita. 2015. Pembangunan Wilayah, Kepulauan, Kelautan Maritim, Terisolasi, Terpencil, Tertinggal, Perbatasan, Pesisir, Pulau-Pulau Kecil,
Archipelago dan Semeja. Yogyakarta: Graha Ilmu.

Rahmat, Aulia. 2018. Partisipasi Politik Masyarakat nelayan Sungai Limau Dalam Pemilu Legislatif Tahun 1999. Jurnal. Padang. Jurnal Bakaba, Volume 8, Nomor 2, bulan Desember.

Rilus A Kinseng. 2011. Konflik Kelas Nelayan di Indonesia, Tinjauan Kasus Balik Papan, Bogor: IPB Press .

Rokhmin Dahuri. 2001. Pengelolaan Sumber Daya Wilayah Pesisir dan Lautan Secara Terpadu. Jakarta: Pradnya Paramita.

Setiawan. Ocky. 2005. Transmigrasi Lokal di Nagari Air Haji Kecamatan Linggo Sari Baganti Kabupaten Pessir Selatan Tahun 1988-2000. Skripsi Padang: Universitas Andalas.

Sudirman. 2013. Mengenal Alat dan Metode Penangkapan Ikan. Jakarta: Rineka Cipta.

Sufirudin. 2016. "Hubungan Patron-Klein Di antara Masyarakat Nelayan di Desa Kangkunawe Kecamatan Maginti Kabupaten Muna Barat Provinsi Sulawesi Tenggara". Jurnal Holistik No.17A.

Supriyanto. 2013. Pelayaran Perdagangan di Pelabuhan Palembang 1824-1864. Yogyakarta: Ombak.

Syahrizal, dkk. 2011. "Aspek Tindakan dan Perilaku dalam Kemiskinan: Studi Pada Masyarakat Nelayan Kabupaten Pesisir Selatan Sumatera Barat". Jurnal Humanus Vol.X. No.1.

Zubir, Zaiyardam. 2008. Profil Kebudayaan Kabupaten Pesisir Selatan". Laporan Penelitian. Padang: Kerjasama Bappeda Pesisir Selatan dan PSH Unand. 